\title{
ASSESSMENT OF LICHENS' METABOLIC AND DEGRADATION PRODUCTS AT DORNAVA MANOR
}

\author{
P. Ropret a, *, š. Tavzes a, K. Retko a, L. Legan a, T. špec, a, N. Ocepek, a \\ a Research Institute, Conservation Centre, Institute for the Protection of the Cultural Heritage of Slovenia, Poljanska 40, 1000 \\ Ljubljana, Slovenia - (polona.ropret, crtomir.tavzes, klara.retko, lea.legan, tanja.spec, nadja.ocepek)@rescen.si
} KEY WORDS: Lichens, Stone objects degradation, Raman microscopy, Pulvinic acid derivatives, Oxalate degradation, Dornava
Manor

\begin{abstract}
:
Five major types of lichen were discovered in the investigated specimens from Dornava Manor. All these lichens and/or their combinations are considered common lichenous overgrowth for the region and its climate. For all of the positively identified lichen species, it is common that they are found on a wide variety of calciferous or base-rich substrata, incl. mortar, brick, roofing tiles, walls, also in large urban areas (are not particularly disturbed by pollution/eutrophication), therefore preferring neutral to basic environment. They are well adapted to sunlight (from scarce direct solar irradiation to sites with very high direct solar irradiation) and can tolerate low water accessibility.

In some of the lichens parietin, an orange organic pigment, was found, indicating the sun exposed areas. Additionally, carotenoids and pulvinic acid derivatives were identified, from which the metabolic pathway of lichens can be determined. These products can also represent biomarkers that can be linked to the survival strategies of lichen communities in stressed environmental habitats.

For many of the investigated samples the lichens' degradation products like oxalates were identified, mainly calcium oxalate Weddellite, while the ammonium oxalate Oxammite is also possible.
\end{abstract}

\section{INTRODUCTION}

The Baš Fortress and Dornava Manor are the two historical sites with different backgrounds that were selected to be the focus point of the multidisciplinary research project HEROMAT, directed towards the development of innovative environmental friendly materials with value added functions aimed to the protection of immovable Cultural Heritage assets. The latter, where the investigation of lichens took part, is the ambitious house complex with accompanying park grounds, covering the area of approximately $3000 \mathrm{~m}^{2}$, and one of the most important monuments of the late Baroque period in Slovenia. It was declared a cultural monument of national importance in the year 1999.

In the past years, the Manor has been studied thoroughly. The investigation, based on the research of archival sources and scientific research, gave a comprehensive image about the architectural history of the manor. It was constructed in many phases on behalf of different Styrian aristocratic families. Among these, the $18^{\text {th }}$ century transformations of the manor are the most significant for giving the building its present form. It was completely rebuilt around the year 1700 by an unknown architect under the patronage of Count Franz Anton Sauer. The rebuilding was finished until 1708 when the ceiling of the Knight's Hall in the main wing was painted with a fresco showing scenes from the life of Hercules and his reception on Mount Olympus by Johann Caspar Waginger. In the first half of the $18^{\text {th }}$ century, the property passed to the Attems family and the Manor was reconstructed once again. On behalf of Count Johann Thaddeus von Attems-Heiligenkreuz and according to the plans of an Austrian architect Joseph Hueber, two courtyard wings were added, new three-story façade with the representative central portal, altana and gable at the top was designed, and the Baroque gardens were constructed (Cigleneški et al, 2003).

In the past, the Manor underwent some minor construction works, which over time severely damaged the building. Because of the long exposure to various environmental factors and inappropriate restoration actions, the exterior elements (façade, statues and other ornaments) today show only a faint picture of the past splendor of the manor. After several decades of accelerated degradation, the overall revitalization of the manor is inevitable. Therefore, it was selected to be the subject of an in-depth research giving indicators that would stop further deterioration of the manor.

Studies of the biodeterioration of stone and similar (mineral, inorganic) materials are an important, and therefore extensively performed for decades, aspect of outdoor immovable cultural heritage protection and preservation. General stone biodeterioration research is superbly reviewed by Cutler and Viles (2010), and an excellent review of such studies, but focused on cultural heritage, is also available (Smith et al., 2011).

In the last decade, the development of analytical equipment has enabled analysis of stone biodegradation with only micro- or even non-destructive sampling. This approach to development is in line with the UNESCO WORLD HERITAGE CENTRE guidelines (UNESCO WHC, 2011) and is especially emphasised in the priorities of the EU Joint Programming Initiative (JPI) on "Cultural Heritage and Global Change: a new

\footnotetext{
* Corresponding author.
} 
challenge for Europe". Moreover, several research grants have been awarded for the development of new materials and procedures for cultural heritage preservation, using these enhanced analytical techniques. One of them, a currently running and aforementioned project HEROMAT, is the frame in which the presented study was conducted.

The research by other groups has provided the information on several metabolic and degradation products that various (micro)organisms form during the colonisation of stone, and the importance of these substances in their survival strategies (Edwards et al., 2003a, 2003b; Frost, 2004; Castro et al., 2008; Kovašik et al., 2011). The following study presents the efforts to identify and characterise such products using spectroscopic techniques with only micro- or even non-destructive sampling, for better understanding of biodeterioration processes on stone, with the ultimate goal of enhanced immovable cultural heritage preservation.

\section{EXPERIMENTAL}

\subsection{Sampling}

The micro samples were collected from the different locations at the Dornava Manor. The sampling was focused on the stone elements and the facade surfaces with the render and colour finishing layers. The areas were selected according to their composition and expected degradation.

\subsection{Lichens characterisation}

Samples, removed for the analysis of biological growth, were investigated visually, using a stereomicroscope, and using a reflective microscope (Olympus BX 60), connected to a JVC 3$\mathrm{CCD}$ video camera. Photographs of samples were taken using Visible light.

For the determination of lichen types or taxa a visual identification key was employed (Volkmar, 1995a, Volkmar, 1995b). Identifications were subsequently cross-referenced with images on the "ITALIC - The Information System on Italian Lichens" website (Nimis and Martellos, 2007).

After the determination of the present lichens, the samples were embedded in the polyester casting resin, then ground and polished. The cross sections of micro samples were then examined with an Olympus BX 60 microscope connected to a JVC 3-CCD video camera using Visible and Ultraviolet light.

\subsection{Raman microscopy}

Raman spectra of colour layers were recorded using $785 \mathrm{~nm}$ laser excitation line with a Horiba Jobin Yvone LabRAM HR800 Raman spectrometer coupled to an Olympus BXFM optical microscope. The spectra were recorded using š100 objective lens and 600 grooves / $\mathrm{mm}$ grating, which gave the spectral resolution of $0.83 \mathrm{~cm}^{-1} /$ pixel. The power at the samples was set between 3,6 and $35,8 \mathrm{~mW}$ using neutral density filters. A multi-channel, air cooled CCD detector was used, with integration times between 20 and 50 seconds, and the spectral range was set between 50 and $1800 \mathrm{~cm}^{-1}$. The wave number calibration was performed using a silicon wafer. Spectra are presented with no baseline corrections.

\section{RESULTS AND DISCUSSION}

As a visual identification key was employed for the determination of lichen types or taxa, a well-developed sexual reproduction structures were required for positive determination on the level of individual species. Unfortunately, often the samples did not contain such structures (the lichen in the incipient stages of growth, etc.). In such cases, the determination was done on the genus level, or a broader morphological description was given.

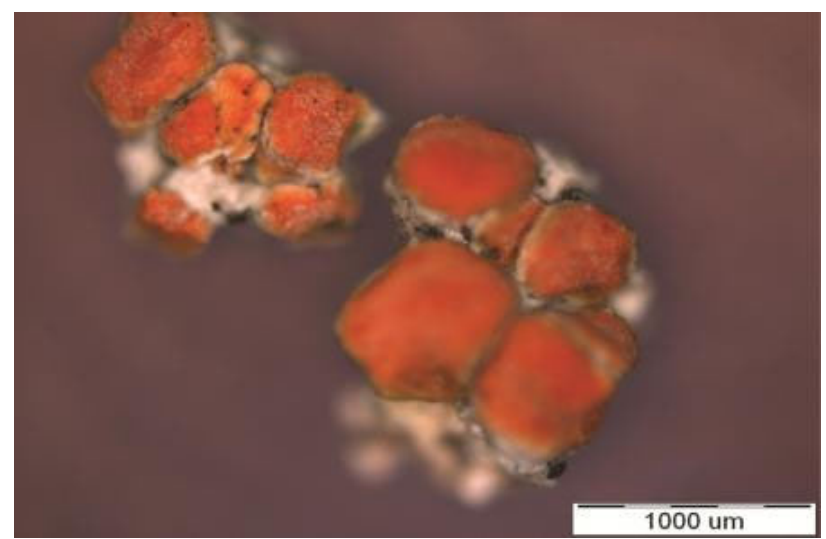

Figure 1: Caloplaca sp. (sample DOR143).

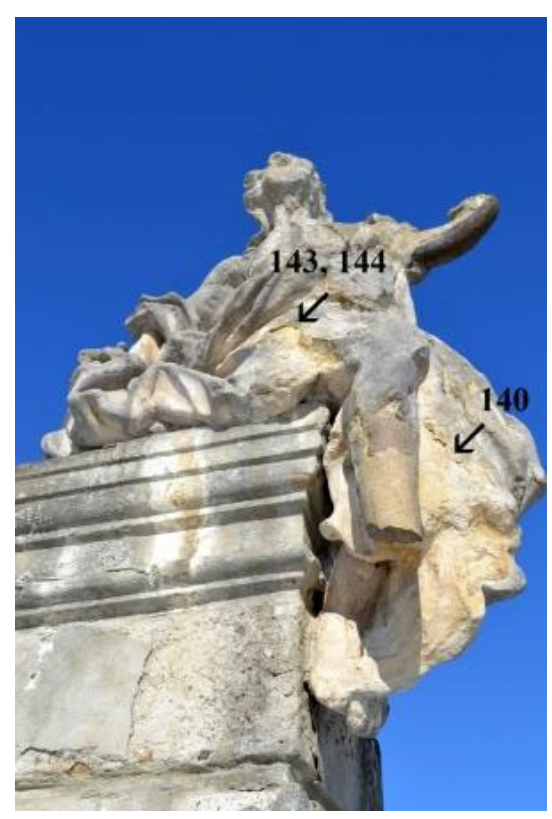

Figure 2: Location of sampling DOR 143.

Overall, five major types of lichen infestation were discovered in the investigated specimens: Candelariella sp. (C. medians, $C$. aurella); Lecanora sp. (L. albescens, L. dispersa); Caloplaca $s p$. (C. citrina); dark brown, dark gray to black-coloured crustose sterile cyanolichen (containing a cyanobacterium as a photobiont); un unidentifiable crustose lichen thallus. Figure 1 shows an example of identified Caloplaca $s p$. removed from a stone sculpture at Dornava manor site (see Figure 2).

Raman analysis of lichens is usually done by using FT-Raman systems and $1064 \mathrm{~nm}$ laser excitation (Schrader et al., 1999; Edwards et al., 1999, 2003a, 2003b; Castro et al., 2008; Gamsjaeger et al., 2011). Most of the enzymes and coenzymes of lichens absorb in the visible range of the spectrum and are 
photo-chemically sensitive, so the spectra are strongly overlaid by fluorescence even when those compounds are present in traces. Therefore, the use of a visible excitation (633 and 514 $\mathrm{nm})$ gave no useful Raman data. However, by the utilisation of the dispersive Raman system with $785 \mathrm{~nm}$ excitation, it was possible to obtain some interesting results on the presence of pigments and metabolic products of lichens, as well as oxalates as a consequence of their degradation processes.

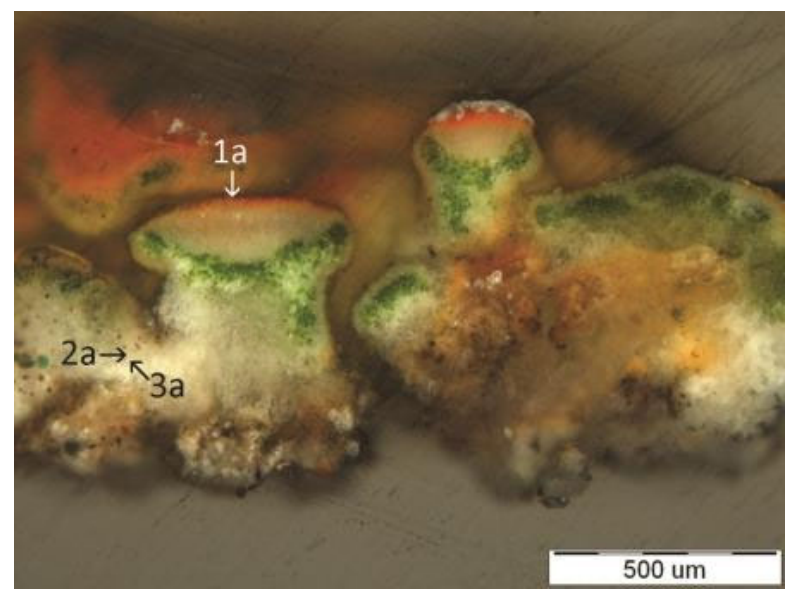

Figure 3: Photomicrograph of the cross - section of lichen prepared with DOR 143 sample, including locations $(1 \mathrm{a}-3 \mathrm{a})$ of Raman analysis.

The Raman spectra of the orange areas (see for example Figure 3 , analysis of spot 1a) of lichens were strongly hindered by fluorescence. However, the weak bands, shown in Figure 4, at $1669(\delta(\mathrm{C}=\mathrm{O})$ conjugated), 1277 (in plane ring stretch), 928 ( $\delta(\mathrm{C}-\mathrm{H})$ out of plane), 467,458 , and $157 \mathrm{~cm}^{-1}$ correspond to the strongest modes of parietin (Edwards et al., 2003a). Parietin is an orange antraquinone pigment. A primary biological role of aromatic pigments in lichens is that of absorbing and filtering solar radiation, especially parietin and atranorin. The colour of lichen can appear from orange - red in highly illuminated sites and greyish yellow in shaded sites, due to the fact that the concentration of parietin is 5 times greater in the sun exposed areas (Edwards et al., 2003a; Solhaug et al., 2003). The orange colour of some lichens found at the Dornava manor site is therefore not connected to the presence of another lichen type, but dependent on the higher concentration of a pigment responsible for the colour.

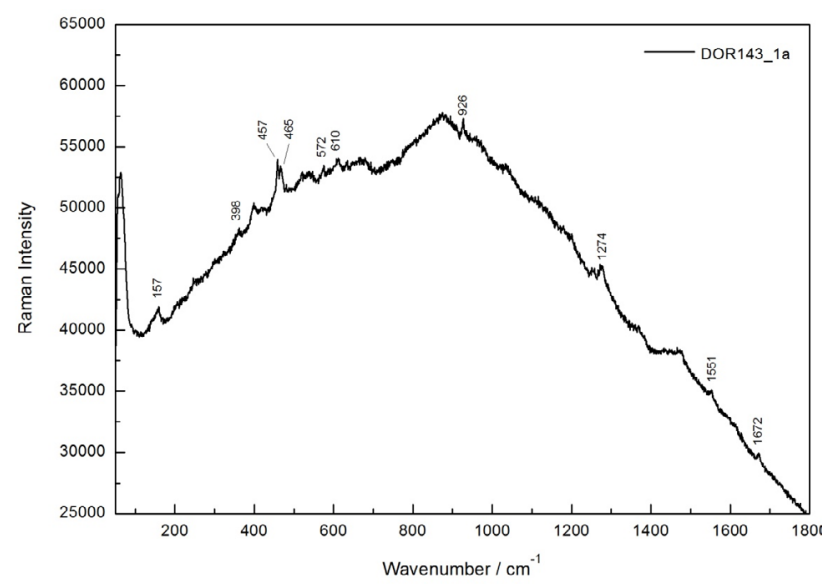

Figure 4: Raman spectrum obtained at the orange layer in the cross - section of DOR143 sample.

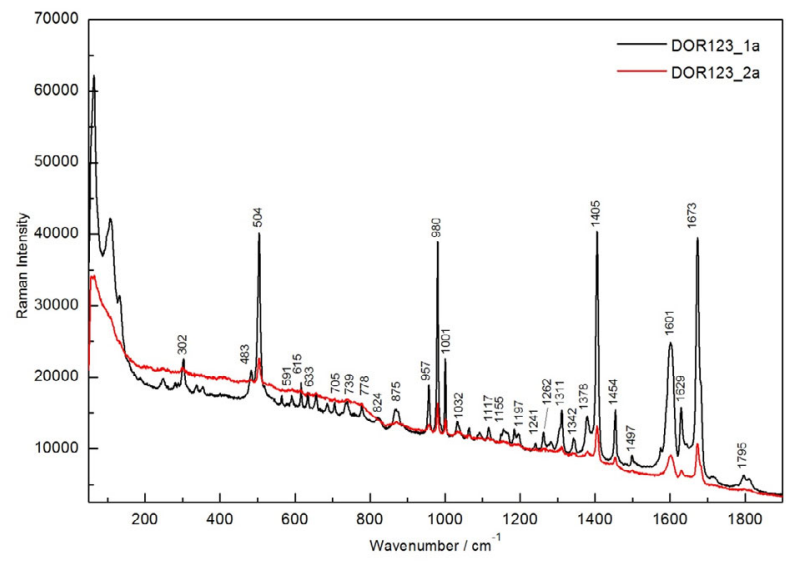

Figure 5: Raman spectra obtained at spots $1 \mathrm{a}$ and $2 \mathrm{a}$ on yellowish orange areas of sample DOR123.

On the other hand, the yellowish - orange areas of lichens present at Dornava can be correlated also to the presence of lichens' metabolic products. Analyses of such areas on sample DOR 123 showed the presence of pulvinic dilactone (Figure 5), with significant Raman modes at $1795(\delta(\mathrm{C}=\mathrm{O})$ lactone $), 1673$ $(\delta(\mathrm{C}=\mathrm{C})$ arom $), 1601(\delta(\mathrm{C}=\mathrm{C})$ furan $), 1497,1454(\delta(\mathrm{C}=\mathrm{C})$ furan; $\left(\delta\left(\mathrm{CH}_{3}\right)\right), 1405(\delta(\mathrm{CH})), 1311(\delta(\mathrm{C}-\mathrm{O}-\mathrm{C})$ lactone, conj'd), 1197, 1117, 1001( $\delta(C C)), 980$ (ring deformation), 824 (ring deformation), 739, 705, 615, 504, and $302 \mathrm{~cm}^{-1}$ (Edwards et al., 2003b).

The remaining bands of weaker intensity can be assigned to calycin, produced by lichens in the same metabolic pathway as pulvinic dilactone. However, due to overlapping with the strong signature of pulvinic dilactone the correlation with calycin is considered tentative, although the bands at $1629(\delta(\mathrm{C}=\mathrm{C})$ arom $), 1378,1342(\delta(\mathrm{COH})$ alcohol $), 1262(\delta(\mathrm{CCO})$ as alcohol), 1241, 1155, 1032 (ring deformation), 957 (ring deformation), 875 (ring deformation), $778(\delta(\mathrm{CCO}) \mathrm{s}$ alcohol), 633,591 ( $\delta(\mathrm{CCO})$ furan), and $483 \mathrm{~cm}^{-1}$ are in good agreement with the Calycin published data (Edwards et al., 2003b).

For many green areas of the lichens' samples Raman spectra showed relatively weak bands, but still, it was possible to correlate them to the strongest modes of chlorophyll and carotenoids.

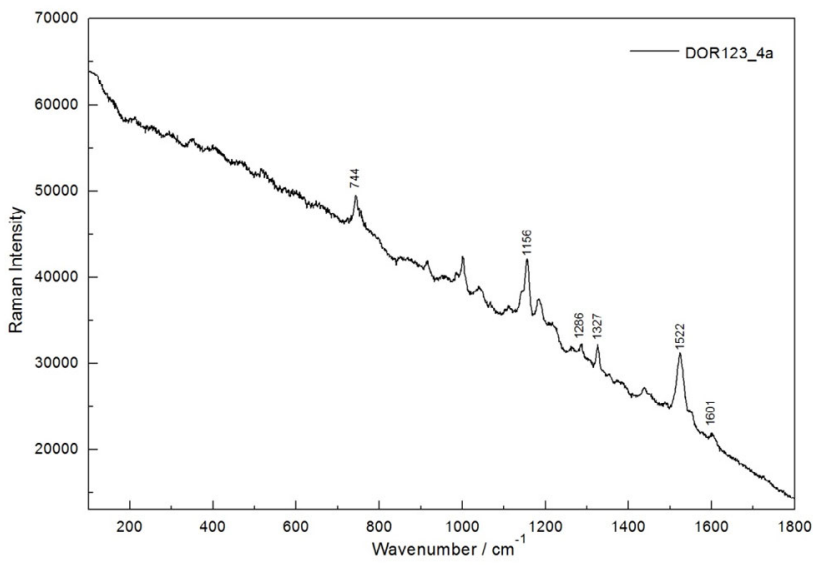

Figure 6: Raman spectrum obtained on a green area of sample DOR123. 
Figure 6 shows the Raman spectrum recorded on the selected green area of sample DOR 123, with Raman shifts significant for the most intense modes of chlorophyll $(1329,1287$, and 744 $\mathrm{cm}^{-1}$ ) and carotenoids (1526, and $\left.1154 \mathrm{~cm}^{-1}\right)$. Although the bands appear in weak intensities, these peaks were determined as markers for both substances by several authors (Schrader et al., 1999; Vitek et al., 2010; Gamsjaeger et al, 2011). Carotenoids are protective against photostress and oxidation. Additionally, they are also known as one of the metabolic products of the lichens following the mevalonic acid pathway, while pulvinic dilactone and calycin are pulvinic acid derivatives, one of the metabolic products of lichens when shikimic acid pathway is active. Depending on the environmental stress, the lichens will have different metabolic pathways employed, and their products can also represent biomarkers that can be linked to the survival strategies of lichen communities in stressed environmental habitats (Edwards et al., 2003b; Solhaug et al., 2003; Kovašik et al., 2011).

The above described Raman results on the presence of parietin, pulvinic dilactone, calycin, chlorophyll and carotenoids can give mainly the data on the environmental stress an object was exposed to, that needs to be taken into account for designing safe treatments for objects of cultural significance. But, the real damage, which needs to be addressed with caution, the lichens cause to these objects is the formation of oxalates, which were found in several samples from Dornava manor.

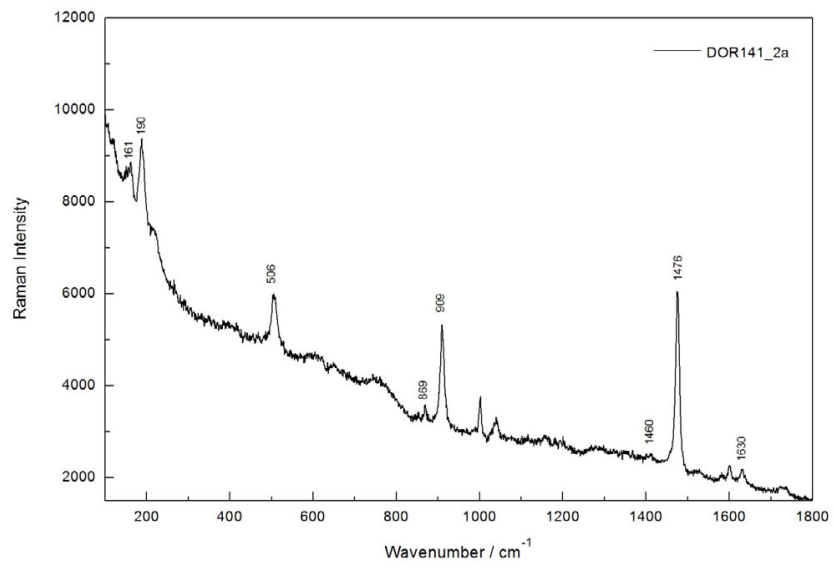

Figure 7: Raman spectrum obtained on the sample DOR 141.

Figure 7 shows the presence of the Calcium oxalate $\left(\mathrm{CaC}_{2} \mathrm{O}_{4} \breve{5} 2 \mathrm{H}_{2} \mathrm{O}\right)$ Weddellite with bands at $1630\left(\delta_{\mathrm{a}}(\mathrm{C}=\mathrm{O})\right)$, $1476\left(\delta_{\mathrm{a}}(\mathrm{C}=\mathrm{O})\right), 1460\left(\delta_{\mathrm{s}}(\mathrm{C}-\mathrm{O})+\delta(\mathrm{C}-\mathrm{C})\right), 909\left(\delta_{\mathrm{s}}(\mathrm{C}-\mathrm{O})+\delta(\mathrm{O}-\right.$ $\mathrm{C}=\mathrm{O})), 869\left(\delta_{\mathrm{s}}(\mathrm{C}-\mathrm{O}) / \delta(\mathrm{O}-\mathrm{C}-\mathrm{O})\right), 506(\delta(\mathrm{M}-\mathrm{O})+\delta(\mathrm{C}-\mathrm{C})), 190$ (lattice modes), and $161 \mathrm{~cm}^{-1}$ (Edwards et al., 2003c; Frost, 2004; Castro et al., 2008). In some of the samples also the presence of the ammonium oxalate Oxammite $\left.\left(\left(\mathrm{NH}_{4}\right)_{2}\left(\mathrm{C}_{2} \mathrm{O}_{4}\right) \check{\mathrm{s}}_{2} \mathrm{O}\right)\right)$ is possible (spectrum not shown).

It is interesting to note that in all these samples lichens containing Lecanora sp. were identified, possibly implying that Lecanora is a strong oxalate producer (Edwards et al., 2003c).

\section{CONCLUSIONS}

Five major types of lichen infestation were discovered in the investigated samples: Candelariella sp. (C. medians, $C$. aurella); Lecanora sp. (L. albescens, L. dispersa); Caloplaca sp. (C. citrina); dark brown, dark gray to black-coloured crustose sterile cyanolichen (containing a cyanobacterium as a photobiont); crustose lichen thallus.

All these lichens are considered common lichenous overgrowth for the region and its climate, and it is common that they are found on a wide variety of calciferous or base-rich substrata, including mortar, brick, roofing tiles, walls, also in large urban areas, and are not particularly disturbed by pollution/eutrophication. They are also well adapted to sunlight and can tolerate low water accessibility.

Utilising Raman microscopy, it was possible to obtain some interesting results on the presence of pigments and metabolic products of lichens, as well as oxalates as a consequence of their degradation processes. Some orange-coloured areas showed the presence of parietin, which is an orange antraquinone pigment, and its quantity can be 5 times greater in the sun exposed areas.

The yellowish - orange areas of lichens were correlated also to the presence of lichens' metabolic products (pulvinic dilactone and calycin). For many green areas of the lichens' samples, Raman spectra showed the presence of chlorophyll and carotenoids (also offer protection against photostress and oxidation).

Carotenoids are synthesised in a different metabolic pathway (mevalonic acid pathway) then pulvinic acid derivatives (pulvinic dilactone and calycin - shikimic acid pathway). Detecting and differentiating between these metabolites can potentially establish procedures of linking these biomarkers to the survival strategies of lichen communities in stressed environments.

The presence of parietin, pulvinic dilactone, calycin, and carotenoids can offer insight on the environmental stress an object was exposed to, which needs to be taken into account for designing safe treatments of cultural heritage in outdoor environment. However, the direct damage the lichens cause to these objects is the formation of oxalates, which were found in several samples (mainly Weddellite, possibly Oxammite). Interestingly, all these samples contained the lichen Lecanora $s p$., possibly implying that it is a strong oxalate producer.

The results obtained and the knowledge gathered during the research work presented in this publication will support and streamline future work within the HEROMAT project.

\section{REFERENCES}

Castro, K. (et al.), 2008. Green Copper Pigments Biodegradation in Cultural Heritage: From Malachite to Moolooite, Thermodynamic Modeling, X-ray Fluorescence, and Raman Evidence. Analytical Chemistry, 80, pp. 4103-4110.

Cigleneški, M. (et al.), 2003. DORNAVA: Vrišerjev zbornik. Cigleneški, M. (Ed.). Slovensko umetnostnozgodovinsko društvo, Filozofska fakulteta, Ljubljana, Book.

Cutler, N., Viles, H., 2010. Eukaryotic microorganisms and stone biodeterioration. Geomicrobiology Journal, 27(6), pp. 630-646.

Edwards, H.G.M. (et al.), 1999. Vibrational Raman spectroscopic study of scytonemin, the UV-protective 
cyanobacterial pigment. Spectrochimica Acta Part A, 56, pp. 193-200.

Edwards, H.G.M. (et al.), 2003a. Molecular spectroscopic studies of lichen substances I: parietin and emodin. Journal of Molecular Structure, 648, pp. 49-59.

Edwards, H.G.M. (et al.), 2003b. Molecular structural studies of lichen substances II: atranorin, gyrophoric acid, fumarprotocetraric acid, rhizocarpic acid, calycin, pulvinic dilactone and usnic acid. Journal of Molecular Structure, 651653 , pp. 27-37.

Edwards, H.G.M. (et al.), 2003c. FT-Raman spectroscopy of lichens on dolomitic rocks: an assessment of metal oxalate formation. Analyst, 128, pp. 1218-1221.

Frost, R. L., 2004. Raman spectroscopy of natural oxalates. Analytica Chimica Acta, 517(1-2), pp. 207-214.

Gamsjaeger, S. (et al.), 2011.Discrimination of carotenoid and flavonoid content in petals of pansy cultivars (Viola $\mathrm{x}$ wittrockiana) by FT-Raman spectroscopy. Journal of Raman Spectroscopy, 42, pp. 1240-1247.

Kovašik, J. (et al.), 2011. Physiological responses of root-less epiphytic plants to acid rain. Ecotoxicology, 20, pp. 348-357.

Nimis, P.L., Martellos, S., 2007. ITALIC - The Information System on Italian Lichens. Deptartment of Biology, University of Trieste, Trieste, Italy. http://dbiodbs.univ.trieste.it/ (accessed Feb. - May 2012)

Schrader, B. (et al.), 1999. Non-destructive NIR FT Raman analysis of plants. Journal of Molecular Structure, 509, pp. 201212.

Smith, B. J. (et al), 2011. Climate change and the investigation of complex moisture regimes in heritage stone: preliminary observations on possible strategies. Materials Evaluation, 69(1), pp. $48-58$.

Solhaug, K. A. (et al), 2003. UV-induction of sun-screening pigments in lichens. New Phytologist, 158, pp. 91-100.

UNESCO WHC, 2011. Operational Guidelines for the Implementation of the World Heritage Convention. UNESCO WHC 11/01, pp. 57-58.

Vitek, P. (et al), 2010. Microbial colonization of halite from the hyper-arid Atacama Desert studied by Raman spectroscopy. Phil. Trans. R. Soc., 368, pp. $3205-3221$.

Volkmar, W., 1995a. Die Flechten Baden-Württembergs Teil 1 \& Teil 2. Eugen Ulmer GmbH \& Co., Stuttgart, 2. Auflage.

Volkmar, W., 1995b. Flechtenflora; Bestimmung und ökologische Kennzeichnung der Flechten Südwestdeutschlands und angrenzender Gebiete (2. neubearbeitete und ergänzte Auflage), Verlag Eugen Ulmer Stuttgart.

\section{ACKNOWLEDGEMENTS}

The research leading to these results has received funding from the European Union Seventh Framework Programme (FP7/2007-2013) under grant agreement $n^{\circ} 282992$.

Project acronym: HEROMAT

Project title: PROTECTION OF CULTURAL HERITAGE OBJECTS WITH MULTIFUNCTIONAL ADVANCED MATERIALS

Coordinator: Faculty of Technology, University of Novi Sad, Novi Sad, Serbia

Research area: ENV-NMP.2011.3.2.1-1 Development of advanced compatible materials and techniques and their application for the protection, conservation and restoration of cultural heritage assets

Type of funding scheme: SME targeted Collaborative Project Web address: www.heromat.tf.uns.ac.rs 
